\title{
ANALISIS PENGARUH ATRIBUT INFLUENCER MARKETING PRODUK ELEKTRONIK PADA PLATFORM YOUTUBE TERHADAP CUSTOMER PURCHASE INTENTION
}

Submitted Date :

1 Agustus 2020

Accepted Date :

30 September 2020
Timothy Rey Laheba

Universitas Atma Jaya Yogyakarta timothy.rey@uajy.ac.id

The Jin Ai

Universitas Atma Jaya Yogyakarta the.jinai@uajy.ac.id

\section{Suggested Citation:}

Laheba, T.R., Jin Ai, T. 2020. Analisis Pengaruh Atribut Influencer Marketing Produk Elektronik pada Platform Youtube terhadap Customer Purchase Intention. Jurnal Bisnis dan Manajemen, Volume 7, № 2, 2020.

\section{Abstract:}

The seemingly unlimited world makes competition increasingly fierce in the electronics industry. This phenomenon makes the industry always look for ways to maximize the competitive advantage of the company. One of them is the marketing strategy. The use of influencer marketing is on the rise and will be able to increase the potential success of a product and brand on the market. But that does not mean the selection and use of influencer marketing can be done easily. Increasing of alternatives and high prices are the main problems during the selection process of influencer marketing faced by the industry. This study tries to find what attributes are the main focus for potential consumers in making product purchase decisions when watching video reviews on the Youtube platform. Data from 172 respondents were collected and analyzed in this research. It was found that the detail of product exposition is the most crucial attribute in making a purchase decision for a product and, if executed well, will ultimately increase customer purchase intentions of potential consumers. They are using video reviews on the YouTube platform.

Keywords Influencer marketing, Product review, Customer purchase intention

\section{Abstrak:}

Dunia yang seolah tanpa batas membuat persaingan yang semakin ketat dalam industri elektronik. Hal ini membuat para pelaku industri selalu mencari cara untuk memaksimalkan competitive advantage yang dimiliki oleh perusahaan. Salah satunya dalam strategi pemasaran, penggunaan influencer marketing akan mampu meningkatkan kesuksesan sebuah produk dan merk di pasaran. Namun bukan berarti pemilihan dan penggunaan influencer marketing dapat dilakukan dengan mudah. Alternatif yang semakin banyak dan harga yang semakin mahal adalah masalah utama dalam pemilihan influencer marketing yang dihadapi oleh para pelaku industri. Penelitian ini mencoba menemukan atribut apa yang menjadi fokus utama bagi para calon konsumen dalam pengambilan keputusan pembelian produk saat menonton review video pada platform Youtube. Data dari 172 orang responden dikumpulkan dan dianalisis sehingga didapatkan bahwa detail eksposisi produk merupakan atribut utama yang paling penting dalam pengambilan keputusan pembelian sebuah produk dan akhirnya akan meningkatkan customer purchase intention dari para calon konsumen pengguna video review pada platform Youtube.

Kata Kunci Customer purchase intention, Influencer marketing, Review produk,

JEL Classification: M31 


\section{Pendahuluan}

Teknologi dan dunia industri merupakan bagian yang tidak dapat terpisahkan pada masa sekarang ini. Kita telah meninggalkan revolusi industri 3.0 dan memasuki masa revolusi industri 4.0 yang akan semakin memaksimalkan dan memperkuat peran teknologi dan komputerisasi dari masa sebelumnya (Tay dkk., 2018). Jika pada masa sebelumnya peran teknologi yang begitu dominan hanya terdapat pada sektor produksi, saat ini seluruh sektor industri telah memanfaatkan teknologi untuk memaksimalkan dan mengefisiensikan proses-proses yang berlangsung didalamnya. Saat ini teknologi telah digunakan mulai dari tahapan awal seperti desain produk sampai dengan proses akhir yaitu penjualan produk kepada konsumen. Oleh karena manfaatnya yang sangat besar, para pelaku industri akan selalu mencoba untuk menganalisis dan memaksimalkan peran teknologi ini dalam rangka memperbaiki model bisnis yang mereka jalankan (Cavalcante, 2013).

Revolusi industri 4.0 dan teknologi berpengaruh dengan sangat masif pada proses pemasaran produk kepada konsumen. Divisi pemasaran dan penjualan merupakan lini industri yang terpengaruh dengan sangat cepat oleh perkembangan teknologi. Teknologi telah memberikan peluang dan pilihan bagi sebuah perusahaan atau brand untuk memasarkan produknya (Glucksman, 2017). Seperti telah kita ketahui bersama praktek pemasaran dengan cara-cara tradisional telah dilakukan sebelumnya oleh seluruh perusahaan yang ada di dunia dan sudah sangat sedikit inovasi yang dapat dilakukan dalam praktek-praktek pemasaran ini. Sekarang kita telah memasuki era baru dengan online marketing yang membawa begitu banyak peluang dan potensi (Schwarzl dan Grabowska, 2015). Pemanfaatan big data dan kustomisasi pemasaran berdasarkan preferensi masing-masing konsumen telah menciptakan proses pemasaran yang lebih baik, presisi dan efisien bagi para pelaku industri.

Word of mouth atau rekomendasi dari orang lain merupakan salah satu metode pemasaran dengan dampak yang paling baik terhadap customer purchase intention (Coll and Mico Sanz, 2019). Salah satu strategi pemasaran yang sudah ada sejak masa lalu dan sampai saat ini masih terus digunakan karena efeknya yang baik adalah penggunaan word of mouth untuk mendorong pembelian. Penelitian menemukan bahwa dalam proses pembelian sebuah produk para konsumen akan sangat dapat dipengaruhi oleh rekomendasi yang berasal dari orang lain (Nawaz dkk, 2014). Rekomendasi yang dapat dijadikan pemicu pembelian sebuah produk ini dapat berupa saran dan review terkait sebuah produk yang sedang dicari dan akan dibeli oleh para konsumen.

Salah satu rekomendasi yang sangat diandalkan oleh para pelaku industri pada masa sekarang ini adalah rekomendasi yang berasal dari para influencer marketing. Jika pada masa lalu word of mouth atau rekomendasi hanya berasal dari saudara, teman ataupun orang-orang dekat yang daya jangkaunya relatif tidak terlalu luas dan terbatas. Namun saat ini semakin masifnya penggunaan teknologi dan perkembangan sosial media telah meningkatkan dampak dan manfaat dari word of mouth (Trusov et al., 2009). Hal ini dikarenakan teknologi akan mampu memperluas jangkaun dari word of mouth yang disampaikan. Bentuk word of mouth ini disebut dengan electronic word of mouth, orang-orang yang akan menyampaikan e-wom ini disebut dengan influencer marketing. Influencer marketing didefinisikan sebagai orang-orang tertentu yang memiliki kemampuan untuk menyebarkan review atau rekomendasi sebuah produk kepada para pengikutnya di dunia maya (Elli, 2017).

Seiring berjalannya waktu penggunaan influencer marketing terus meningkat dengan sangat pesat dari tahun ke tahun. Berkat peran dan manfaatnya yang sangat baik, ada banyak perusahaan yang mengintegrasikan penggunaan influencer marketing dalam strategi pemasaran produk mereka. Saat ini mayoritas (66\%) pelaku pemasaran melakukan kampanye dengan influencer marketing paling tidak 2 kali dalam 1 tahun (Linqia, 2019). Laporan yang sama menyatakan bahwa $57 \%$ responden lebih mempercayai konten promosi yang berasal dari para influencer dibandingkan dengan konten yang dihasilkan oleh sebuah merk dalam bentuk iklan. Sesungguhnya penggunaan influencer marketing bukanlah hal baru dalam dunia industri. Namun pada masa lalu influencer marketing terbatas hanya pada selebritis atau public figure. Namun saat ini berkat keterbukaan informasi, siapa saja yang memiliki banyak pengikut atau follower di dunia maya dapat menjadi saluran penyebaran informasi yang baik bagi sebuah produk atau merk.

Persaingan dalam industri elektronik (smartphone dan komputer jinjing) semakin intensif. Industri produkproduk elektronik tengah menghadapi persaingan yang sangat berat. Sebagai ilustrasi pada produk smartphone yang dulu hanya dikuasai oleh brand Samsung dan Apple, dunia yang saat ini seperti tanpa batas telah membawa begitu banyak merk baru untuk berkompetisi pada pasar ini. Merk baru seperti Xiaomi, Oppo, Huawei dan masih banyak lagi saat ini sudah begitu mudah dijumpai di pasaran. Market share produk smartphone dapat dilihat pada Tabel 1.

Tabel 1. Market share produk smartphone di Indonesia (Zakiah, 2020)

\begin{tabular}{|l|l|l|}
\hline No & Brand Smartphone & Market share \\
\hline
\end{tabular}




\begin{tabular}{|l|c|c|}
\hline & & \\
\hline 1 & Samsung & $25.75 \%$ \\
\hline 2 & Xiaomi & $20.98 \%$ \\
\hline 3 & Oppo & $18.42 \%$ \\
\hline 4 & Iphone & $5.52 \%$ \\
\hline 5 & Asus & $4.08 \%$ \\
\hline 6 & Lenovo & $1.85 \%$ \\
\hline 7 & Huawei & $1.13 \%$ \\
\hline
\end{tabular}

Hal menarik lainnya merk-merk baru ini tidak lagi hanya berfokus mengeluarkan produk pada seri entry level atau harga rendah tapi juga pada seri terbaik atau yang biasa disebut dengan flagship, dengan tentu saja middle range yang ada di kisaran harga 3-4 juta rupiah sebagai area persaingan yang paling ketat dan keras (Kumparan, 2019). Selain itu tumbuhnya segmen pasar baru seperti gamer dan bisnis juga menambah jenis dan variasi produk yang diluncurkan ke pasaran dan pada akhirnya akan menambah persaingan. Persaingan yang sangat ketat ini telah mengubah karakter produk dalam industri ini. Saat ini siklus hidup produk smartphone semakin pendek karena dalam tempo yang singkat akan ada begitu banyak produk sejenis yang akan membanjiri pasar, potongan harga yang besar bukan lagi hal yang asing bagi produk elektronik karena kompetisi yang sangat ketat saat ini. Fenomena ini akan memaksa para pelaku industri elektronik selalu mencari cara untuk memaksimalkan penjualan melalui proses pemasaran pada produk-produknya. Produk elektronik adalah salah satu produk yang dapat mengandalkan online review dan rekomendasi sebagai media utama untuk pemasaran produknya. Penelitian menunjukkan konsumen produk elektronik merupakan konsumen yang paling terpengaruh oleh online review saat melakukan proses pembelian (Barbado dkk, 2019). Fenomena ini dikarenakan produk elektronik merupakan produk yang membutuhkan investasi cukup besar dan pembelian cukup sering dilakukan oleh para konsumen, rata-rata orang indonesia akan mengganti perangkat smartphonenya setiap 24 bulan, sehingga pembelian harus dilakukan dengan hati-hati dan penuh pertimbangan. Hal ini juga ditambah dengan begitu beragamnya pilihan yang ditawarkan kepada konsumen sehingga konsumen membutuhkan review dan rekomendasi untuk mencari dan memutuskan produk mana yang paling tepat untuk kebutuhan mereka.

Para pelaku industri elektronik melakukan investasi dalam jumlah yang besar untuk strategi pemasaran dengan menggunakan influencer marketing. Dengan kemampuannya yang sangat baik dalam menyebarluaskan informasi kepada para pengikutnya, influencer marketing telah menjadi aset yang vital bagi strategi pemasaran produk-produk elektronik. Para influencer ini diberikan produk gratis untuk di review, diskon khusus bagi para pengikutnya dan kompensasi untuk menyebarkan word of mouth yang baik untuk produk atau brand tertentu. Bahkan akhir-akhir ini produsen besar seperti samsung mengundang para influencer dari seluruh negara di dunia termasuk Indonesia untuk datang ke peluncuran produknya, tentu saja dengan sebuah keharusan menghasilkan konten video pada platform Youtube yang pada akhirnya dapat menciptakan hype dan meningkatkan penjualan produk yang akan dilaunching ataupun produk-produk lainnya dari merk tersebut. Pada Gambar 1 dapat dilihat influencer Indonesia diundang dan datang ke event peluncuran produk baru Samsung pada tahun 2020 di San Fransisco, Amerika serikat.

Pemasaran adalah sebuah seni. Sebaik apapun media pemasarannya, jika tidak menjangkau segmen pasar yang tepat maka pemasaran tidak akan dapat berjalan dengan maksimal. Walaupun electronic word of mouth yang dihasilkan oleh para influencer diakui sebagai salah satu metode yang paling baikdalam menciptakan hype dan memasarkan sebuah produk, namun dengan semakin terbukanya dunia dan platformplatform yang ada, saat ini kita melihat ada begitu banyak orang yang mengaku sebagai seorang influencer, hal ini ditambah dengan semakin tingginya biaya word of mouth yang dipatok oleh seorang influencer membuat setiap pelaku industri harus menentukan influencer marketing dengan cermat dan tepat sesuai dengan preferensi dan kebutuhan pasar yang mereka kejar. 


\section{Kajian Literatur}

Setiap Influencer marketing memiliki gaya dan karakter yang berbeda-beda saat menyebarluaskan word of mouth bagi sebuah produk. Sama seperti sebuah produk, walaupun seorang influencer memasarkan sebuah produk yang sama atau sejenis, mereka akan memiliki atribut tersendiri yang tentu saja pada akhirnya akan mempengaruhi segmen pengikutnya masing-masing. Oleh karena itu dalam memilih dan menentukan influencer marketing yang tepat untuk produknya, para pelaku industri harus memperhatikan atribut yang dimiliki oleh para influencer. Agar proses pemasaran yang berlangsung dapat berjalan dengan efektif dan efisien.

Youtube merupakan salah satu platform alternatif baru dalam dunia pemasaran. Beberapa penelitian telah dilakukan sebelumnya terkait peranan Youtube dalam dunia pemasaran di masa teknologi. Brock (2008) menyatakan bahwa Youtube merupakan sebuah media pemasaran yang menjadi impian para pelaku pemasaran dikarenakan biaya produksi yang rendah, penyebaran informasi yang cepat dan respon konsumen yang cepat dan relevan. Duffett dkk. (2019) menemukan pemasaran melalui platform Youtube akan mempengaruhi preferensi pemilihan sebuah merk pada generasi milenial. Dengan terus bertambahnya jumlah generasi milenial diseluruh dunia khususnya Indonesia, penggunaan platform Youtube sebagai media pemasaran dapat menjadi salah satu alternatif utama bagi para pelaku industri dalam memasarkan produknya.

Jumlah subscriber dan view merupakan salah satu cara yang dapat digunakan untuk meningkatkan efektivitas atau manfaat proses pemasaran melalui video. Costa-sanchez (2017) dalam penelitiannya mencoba untuk menggunakan variabel ini dalam mengukur hubungan antara jumlah subscriber dan jumlah view video pada kanal Youtube yang dimiliki oleh perusahaan-perusahaan terkemuka yang ada di Spanyol. Khan dan Vong (2014) melakukan penelitian untuk menemukan faktor-faktor yang menjadikan sebuah video viral untuk membantu para pelaku pemasaran dalam melakukan pemasaran melalui video. Namun jumlah view dan subscriber dari video ataupun influencer marketing belum menjamin peningkatan penjualan dari suatu produk, sehingga masih dibutuhkan analisis terkait faktor-faktor yang dapat meningkatkan customer purchase intention melalui pemasaran pada platform Youtube.

Interaksi yang baik dan optimal oleh calon konsumen dapat dijadikan salah satu cara untuk meningkatkan keinginan membeli dari konsumen. Wolny dan Mueller (2013) dalam penelitiannya mencoba untuk menemukan faktor faktor yang menyebabkan calon konsumen mempercayai review online yang dibuat oleh orang lain dan pada akhirnya akan meningkatkan keinginan untuk membeli sebuah produk atau jasa. Sotiriadis dan Van zyl (2013) menemukan dalam industri wisata yang dipasarkan melalui sosial media, review yang baik akan mampu meningkatkan keinginan konsumen untuk membeli, menerima dan loyal tehadap sebuah produk. Wendt, Grisbaum dan Kolle (2016) melakukan penelitian terhadap 1080 video yang terbagi kedalam 22 subkategori di Youtube untuk menemukan hubungan antara persepsi calon konsumen terhadap sebuah brand dengan komentar yang ditulis di kolom komentar. Sokolovia dan Kefi (2019) dalam penelitiannya melihat bagaimana hubungan psikologis yang terjadi antara calon konsumen dengan influencer marketing dapat mempengaruhi keinginan membeli dari konsumen.

Influencer marketing akan terus tumbuh dan berkembang. Influencer marketing didefinisikan sebagai seseorang yang terkenal dan "suaranya" didengar oleh calon konsumen yang ditugaskan untuk memasarkan atau memperkenalkan sebuah produk dengan harapan peningkatan penjualan produk tertentu (Shingwenyana, 2019). Kadekova dan Holiencinova (2018) dalam penelitiannya menemukan bahwa Influencer marketing terutama pada platform Youtube akan terus berkembang dan membuka banyak pekerjaan baru.

Walaupun beberapa penelitian sudah dilakukan terkait penggunaan Youtube dan Influencer marketing dalam strategi pemasaran, masih belum banyak penelitian yang dilakukan untuk menemukan cara bagaimana seorang Influencer marketing produk elektronik dapat meningkatkan customer purchase intention melalui konten video yang dibagikan. Dengan mengetahui atribut-atribut apa yang dapat meningkatkan customer purchase intention pemasaran melalui konten video pada platform Youtube akan dapat dilakukan dengan lebih baik oleh para pelaku industri terkhususnya para pelaku industri eketronik yang sedang menghadapi persaingan ketat saat ini.

Tujuan dari penelitian ini adalah mencari atribut-atribut apa saja yang dianggap penting oleh para konsumen yang menggunakan youtube untuk mencari video review produk elektronik yang akan mereka beli. Sementara itu manfaat dari penelitian ini dapat digunakan oleh para pelaku industri khususnya industri elektronik untuk memilih influencer marketing yang akan memiliki dampak paling baik untuk pemasaran merk dan produknya sehingga pada akhirnya proses pemasaran yang dilakukan oleh sebuah perusahaan elektronik dapat berjalan dengan lebih efektif dan efisien.

\section{Methodology}


Penelitian ini akan menggunakan responden dengan instrumen pengambilan data yaitu kuesioner untuk menemukan atribut influencer marketing produk elketronik pada platform Youtube yang dapat mempengaruhi customer purchase intention. Untuk pengolahan data akan menggunakan dua tipe metode statistik yang pertama adalah statistik deskriptif dan statistik inferensial dengan uji friedman two way anova with ranks. Dalam melakukan analisis statistik ini akan dibantu dengan software SPSS.

Populasi dalam penelitian ini adalah seluruh masyarakat indonesia yang mencari dan menonton video review produk elektronik pada platform youtube sebagai alat bantu pengambilan keputusan dalam menentukan produk apa yang paling sesuai dengan kebutuhan mereka. Jumlah sampel dalam penelitian ini adalah 185 orang. Namun setelah proses screening dilakukan hanya data dari 172 responden yang layak untuk diproses lebih lanjut dan digunakan dalam penelitian ini. Sampel yang digunakan dalam penelitian ini adalah mahasiswa pada range umur 17-25 tahun yang merupakan generasi yang sangat loyal dalam menonton video di Youtube dan merupakan generasi yang tidak dapat terpisahkan dari produk elektronik dalam kehidupan kesehariannya. Sampel ini merupakan representasi yang baik dari populasi dalam penelitian ini karena merupakan bagian yang dominan dari populasi.

\section{Hasil Penelitian}

Review merupakan hal yang sangat penting dan tidak terpisahkan dari kehidupan generasi milenial indonesia saat ini. Hal ini terutama dibutuhkan saat melakukan pembelian produk-produk elektronik. Penelitian ini menemukan bahwa $57.6 \%$ responden selalu mencari review sebelum melakukan pembelian produk eletronik, $29.8 \%$ mengaku sering mencari review dan $11 \%$ kadang-kadang mencari review sebelum melakukan pembelian. Sementara itu hanya $2 \%$ responden yang tidak pernah menggunakan atau mencari review sebelum melakukan pembelian produk-produk elektronik.

Review dalam bentuk video merupakan jenis review yang paling banyak dicari jika produk yang akan dibeli adalah produk elektronik. Sebanyak $80.6 \%$ responden memilih review dalam bentuk video, sebuah proporsi yang besar jika dibandingkan dengan $14.1 \%$ yang memilih review dalam bentuk narasi dan $4.2 \%$ yang memilih foto sebagai jenis review yang terbaik. Hal ini juga didukung dengan $84,3 \%$ responden memilih review dalam bentuk video dikarenakan akan memberikan gambaran yang lebih jelas dan detail terkait profil dan atribut dari sebuah produk elektronik.

Youtube merupakan channel atau sumber utama bagi generasi milenial untuk mencari review produk elektronik dalam bentuk video. Dari penelitian ini didapatkan sebanyak $79.1 \%$ responden menyatakan Youtube merupakan pilihan utama ketika mencari review dalam bentuk video sementara $12.1 \%$ lainnya menggunakan website untuk mencari video review dari produk-produk elektronik.

Influencer marketing terutama pada platform Youtube bukanlah hal yang asing bagi generasi milenial di Indonesia. Sebanyak 89,6\% responden menyatakan kalau mereka sangat familiar dengan keberadaan influencer marketing pada platform Youtube. Namun ternyata mereka tidak begitu saja percaya kepada para influencer marketing ini. Ini harus menjadi perhatian bagi para pelaku industri terkhusus industri elektronik karena ternyata bukan selebriti atau public figure melainkan $91 \%$ responden akan mempercayai orang yang paham dan mengerti tentang produk elektronik yang sedang di review selain itu juga mereka tidak akan langsung percaya terhadap perkataan seorang influencer marketing, 87,6\% dari mereka akan melihat atribut yang berkaitan dengan kredibilitas video dan orang yang melakukan review bagi produk elektronik yang ingin mereka beli. Oleh karena itu penelitian ini juga akan mencari tahu atribut mana yang menjadi perhatian utama para generasi milenial dalam memilih influencer marketing mana yang bisa mempengaruhi keputusan meningkatkan customer purchase intention.

Uji Friedman two way anova with ranks digunakan untuk melihat atribut influencer marketing mana yang paling berpengaruh dalam meningkatkan kepercayaan dan customer purchase intention. Berdasarkan hasil uji friedman 2 way anova with ranks yang dilakukan, pada tabel 2 dapat dilihat nilai signifikansi yang didapatkan adalah 0.000 sehingga $\mathrm{H}_{0}$ dalam penelitian ini dapat ditolak yang berarti terdapat perbedaan preferensi dari para customer terhadap atribut yang dimiliki oleh para influencer marketing pada platform Youtube. 


\begin{tabular}{|c|c|c|c|}
\hline Hipotesis Nol & Tes atau Uji & Sig. & Keputusan \\
\hline $\begin{array}{c}\text { Tidak ada perbedaan pengaruh Jumlah } \\
\text { Subscriber, Track Record Influencer, } \\
\text { Jumlah View Video, Kualitas Audio } \\
\text { Visual Video, Detail Eksposisi Produk, } \\
\text { Kejujuran dan Pernyataan Disclaimer } \\
\text { dan Keberadaan Special Link dan } \\
\text { Discount pada customer purchase } \\
\text { intention. }\end{array}$ & $\begin{array}{c}\text { Uji Friedman Two Way Anova with } \\
\text { Ranks }\end{array}$ & .000 & \\
& & & $\begin{array}{c}\text { Tolak } \\
\text { Hipotesis } \\
\text { Nol }\end{array}$ \\
\hline
\end{tabular}
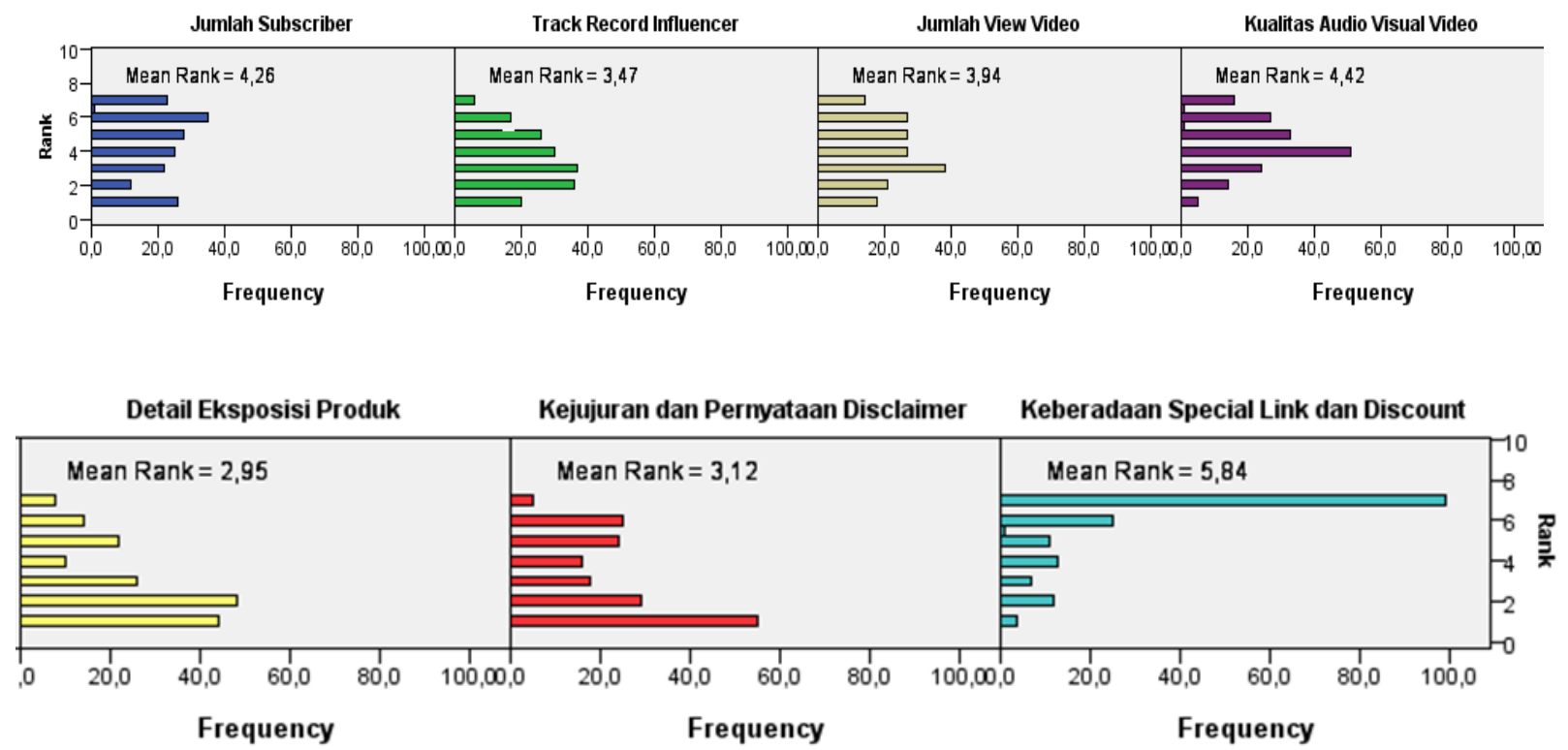

Gambar 2. Nilai rata-rata ranking untuk atribut detail eksposisi produk, kejujuran dan pernyataan disclaimer dan keberadaan special link dan discount

Jika ditelaah lebih dalam nilai rata-rata ranking yang diberikan oleh para responden untuk atribut influencer marketing mana yang paling penting menurut mereka dalam pengambilan keputusan pembelian sebuah produk. Pada Gambar 2 dapat dilihat nilai rata-rata ranking untuk atribut jumlah subscriber adalah 4.26. Nilai rata-rata ranking untuk atribut track record influencer adalah 3.47. Nilai rata-rata ranking untuk atribut jumlah view video adalah 3.94. Nilai rata-rata ranking untuk atribut kualitas audio visual video adalah 4.42. Pada gambar 3 dapat dilihat nilai rata-rata ranking untuk atribut detail eksposisi produk adalah 2.95. Nilai rata-rata ranking untuk atribut kejujuran dan pernyataan disclaimer adalah 3.12. Nilai rata-rata ranking untuk atribut keberadaan special link dan discount adalah 5.84. Dari nilai ranking ini kita akan dapat melihat dan mengambil kesimpulan atribut mana yang lebih mempengaruhi para konsumen produk elektronik dengan semakin tinggi ranking yang diperoleh oleh sebuah atribut menandakan atribut tersebut merupakan atribut yang dianggap paling penting oleh para responden.

\section{Kesimpulan}

Penelitian ini bertujuan untuk menemukan konsep yang paling baik dalam pemilihan influencer marketing yang dapat digunakan untuk menyebarkan electronic word of mouth yang baik kepada para konsumen. Penelitian ini menemukan bahwa bagi generasi milenial Indonesia review sudah menjadi bagian yang tidak terpisahkan. Secara lebih spesifik untuk produk elektronik review yang diberikan oleh seorang influencer marketing dalam bentuk video dipercaya akan sangat membantu mereka dalam proses pengambilan keputusan dalam pembelian sebuah produk. 
Namun tidak semua influencer marketing dengan atribut yang dimilikinya akan berhasil mempengaruhi para konsumen. Penelitian ini menemukan bahwa atribut yang dimiliki oleh seorang influencer marketing akan mampu untuk meningkatkan customer purchase intention dari para calon pembeli produk elektronik. Penelitian ini menemukan bahwa atribut yang dianggap paling penting bagi para calon konsumen adalah detail eksposisi produk, kemudian diikuti dengan kejujuran dan pernyataan disclaimer jika memang sang influencer marketing disponsori oleh perusahaan tertentu, lalu atribut selanjutnya adalah track record influencer, kemudian diikuti dengan jumlah view video, jumlah subscriber, kualitas audio visual video dan terakhir keberadaan link dan discount pembelian sebuah produk.

Penelitian ini mencoba untuk menemukan atribut apa yang paling penting bagi seorang influencer marketing produk elektronik pada platform Youtube. Dalam penelitian selanjutnya penelitian ini dapat dikembangkan dengan melihat sekuat apa pengaruh masing-masing atribut influencer marketing terhadap customer purchase intention dan dampak variabel mediator yang mempengaruhi customer purchase intention para calon konsumen.

\section{References}

Tay, S., Te Chuan, L., Aziati, A. \& Ahmad, At.. (2018) An Overview of Industry 4.0: Definition, Components, and Government Initiatives. Journal of Advanced Research in Dynamical and Control Systems. 10. 14.

Cavalcante, Sérgio. (2013). Paper 4: Understanding the impact of technology on firms' business models. European Journal of Innovation Management. 16. 285-300. 10.1108/EJIM-10-2011-0085.

Glucksman, M. (2017). The Rise of Social Media Influencer Marketing on Lifestyle Branding:A Case Study of Lucie Fink, Elon Journal of Undergraduate Research in Communications, Vol. 8, No. 2 • Fall.

Schwarzl, S., Grabowska M... (2015).Online Marketing Strategies: the Future is Here. Journal of International Studies, Vol. 8, № 2, 2015, 187-196. DOl:10.14254/2071-8330.2015/8-2/16.

Coll, P. \& Micó-Sanz, J. (2019). Influencer marketing in the Growth Hacking strategy of digital brands. Observatorio. 12. 87-105. 10.15847/obsOBS13220191409.

Nawaz, A. \& Vveinhardt, J. \& Ahmed, R. (2014) Impact of Word of Mouth on Consumer Buying Decision. European Journal of Business and Management. 6. 394-403.

Trusov, M., Bucklin, R. E., and Pauwels, K. (2009). "Effects of Word-of-mouth Versus Traditional Marketing: Findings from an Internet Social Networking Site". Journal of Marketing, 73 (5), p. 90-102. http://www.itu.int//TU-D/ict/statistics/, diakses maret 2020.

Elli, D.M.. (2017). The phenomenon and rise of Influencer Marketing and how it affects customer opinion and helps or damages brands. A thesis submitted for the degree ofMaster of Science (MSc) in e-Business and Digital marketing.

Linqia, The State of Influencer Marketing (2019) Influencer Marketing Joins the Big Leagues, (2020). Available: https://linqia.com/wp-content/uploads/2019/04/Linqia-State-of-Influencer-Marketing-2019-Report.pdf

Kumparan. Oppo Tetap Pede Meski Persaingan Smartphone Makin Ketat. [online] Available at: $<$ https://kumparan.com/kumparantech/oppo-tetap-pede-meski-persaingan-smartphone-makin-ketat$1553525847041767330>$ diakses 18 Maret 2020.

Times and N. Zakiah, "Samsung sampai Huawei, 7 Brand Handphone yang Rajai Pasar Indonesia", IDN Times, 2020. [Online]. Available: https://jabar.idntimes.com/tech/gadget/nena-zakiah-1/brand-smartphone-yangmenguasai-market-indonesia-regional-jabar. Diakses : 18- Mar- 2020.

Barbado, R., Araque, O., Iglesias, C.A., (2019). A Framework for Fake Review Detectionin Online Consumer Electronics Retailers. arXiv:1903.12452v1 [cs.CL] 29 Mar.

Brock, T. (2008). Youtube - Marketing in the Age of Now and Wow. Agency Sales; Sep 2008; 38, 9; ABI/INFORM Collection pg 42.

Duffett, R., Petrosanu, D., Negricea, I., Edu, T. (2019). Effect of Youtube Marketing Communication on Converting Brand Liking into Preference among Millennials Regarding Brands in General and Sustainable Offers in Particular. Evidence from South Africa and Romania. . 11. 604. 10.3390/su11030604.

Costa-Sanchez, C. . (2017). Use of Youtube for Business Communication Analysis of the Content Management and Level of Participation of Spanish Best Reputed Companies Youtube Channels. Macmillan Publishers Ltd \& Reputation Institute. 
Khan, G. \& Vong, S. (2014). Virality over Youtube: an empirical analysis. Internet Research. 24. 629-647. 10.1108/IntR-05-2013-0085.

Wolny, Julia \& Mueller, Claudia. (2013). Analysis of fashion consumers' motives to engage in electronic word-ofmouth communication through social media platforms. Journal of Marketing Management. 29. 10.1080/0267257X.2013.778324..

Sotiridis, M., \& Van Zyl, C.. (2013). Electronic World-Of-Mouth And Online Reviews In Tourism Services: The Use Of Twitter By Tourists. Journal of Electronic Commerce Research. Volume 13. pp 103-124. 10.1007/s10660-013-9108-1.

Wendt L., Griesbaum, J., \& Kölle, R. (2016). Product Advertising and Viral Stealth Marketing in Online Videos: A description and comparison of comments on YouTube. Aslib Journal of Information Management. 68. 10.1108/AJIM-11-2015-0174.

Sokolova, K., \& Kefi, H. (2019). Instagram and Youtube bloggers promote it, why should I buy? How credibility and parasocial interaction influence purchase intentions. Journal of Retailing and Consumer Services. 10.1016/j.jretconser.2019.01.011.

Shingwenyana, R. (2019). Influencer marketing - the value of micro vs macro-influencer marketing tactics. Available at https://www.bizcommunity.com/Article/196/669/189653.html.

Kadekova, Zdenka and Holienčinova, Maria. Influencer marketing As A Modern Phenomenon Creating A New Frontier Of Virtual Opportunities, Communication Today, Vol. 9, No. 2. 2018

Artaya, I Putu.. (2018). UJI FRIEDMAN. 10.13140/RG.2.2.25271.98723. you can in addition to the URL. The following examples include some of the most common types of electronic sources. 